\title{
PENERAPAN BASIS DATA CITRA PADA SISTEM PENCARIAN CITRA BERBASIS ISI: MENGGUNAKAN FASILITAS JAVA OBJECT SERIALIZATION DAN MENGGUNAKAN FASILITAS MYSQL
}

\author{
Eliza Margaretha, Eka Aditya, Ade Azurat, Maruli Manurung, dan Aniati Murni
}

Fakultas Ilmu Komputer, Universitas Indonesia, Depok, Indonesia

elm40@ui.edu, aniati@cs.ui.ac.id

\begin{abstract}
Abstrak
Makalah ini membahas dua pilihan penerapan struktur basis data citra pada sistem pencarian citra berbasis isi. Pendekatan pertama menggunakan folder untuk menyimpan berkas citra dan Java object serialization untuk menyimpan data citra. Pendekatan kedua menggunakan basis data Data Base Management System MySQL untuk menyimpan berkas dan data citra. Kedua pendekatan dibahas dari aspek penerapan struktur basis data untuk tujuan pengembangan sistem pencarian citra berbasis isi yang efisien. Data yang tidak terstruktur dan proses clustering data lebih mudah ditangani dengan struktur basis data dari pendekatan pertama. Data yang jumlahnya besar dan terstruktur serta proses indexing lebih mudah ditangani dengan struktur basis data dari pendekatan kedua. Sistem pencarian citra berbasis isi lebih banyak melakukan kueri jenis select dibandingkan dengan insert dan update data, dalam hal ini kedua pendekatan dapat memenuhinya dengan baik. Secara umum, pendekatan kedua dianggap memberikan dukungan yang baik dalam penyimpanan dan manipulasi data, serta dapat mengurangi upaya dan waktu yang dibutuhkan pada pengembangan sistem.
\end{abstract}

Kata kunci : Java object serialization, MySQL, Sistem pencarian citra berbasis isi

\section{Pendahuluan}

Sejumlah besar sistem pengolahan citra telah dibangun untuk berbagai aplikasi, seperti: aplikasi biomedis dan aplikasi penginderaan jarak jauh. Dalam perkembangannya di masa lalu, teknologi pengolahan citra cenderung berkembang lebih pesat dibandingkan dengan teknologi basis data untuk penyimpanan citra. Data citra umumnya dianggap berukuran besar terutama dibandingkan dengan kemampuan atau kapasitas media penyimpan data yang tersedia, sehingga cara penyimpanan data citra telah menjadi masalah yang penting. Sebagai respon terhadap masalah tersebut, orang berusaha melakukan pemampatan data citra agar dapat disimpan pada media penyimpan yang tersedia. Berbagai teknik pemampatan data yang efisien telah banyak dihasilkan.

Pada masa berkembangnya teknologi basis data dan kemajuan teknologi media penyimpanan, kapasitas media penyimpanan data citra tidak lagi merupakan kendala. Berbagai pendekatan dalam membangun struktur basis data citra banyak bermunculan. Mulai dengan penggunaan folder, representasi dalam bit (blob), sampai ke penggunaan codebook. Sistem pencarian citra berbasis isi berfungsi untuk mencari citra-citra pada basis data citra yang serupa dengan contoh citra yang diberikan pemakai sistem. Tingkat keserupaan disini dapat didasarkan pada fitur warna, tekstur, maupun bentuk objek yang ada pada citra terkait [1].

Makalah ini membahas dua pendekatan praktis dalam membangun basis data untuk sistem tersebut diatas. Pendekatan yang pertama menggunakan fasilitas folder dan Java object serialization, sedangkan pendekatan kedua menggunakan fasilitas MySQL DataBase Management System. Kedua pendekatan tersebut selanjutnya dibandingkan dengan melihat aspek-aspek yang dibutuhkan pada pembangunan suatu struktur basis data untuk mendapatkan suatu sistem pencarian citra berbasis isi yang efisien. Salah satu aspek antara lain adalah fasilitas indexing.

Makalah ini disusun sebagai berikut. Pendekatan pertama dibahas di Bagian 2 dan pendekatan kedua dibahas di Bagian 3. Perbandingan kedua pendekatan dibahas di Bagian 4. Selanjutnya, makalah ini ditutup dengan sebuah ringkasan di Bagian 5. 


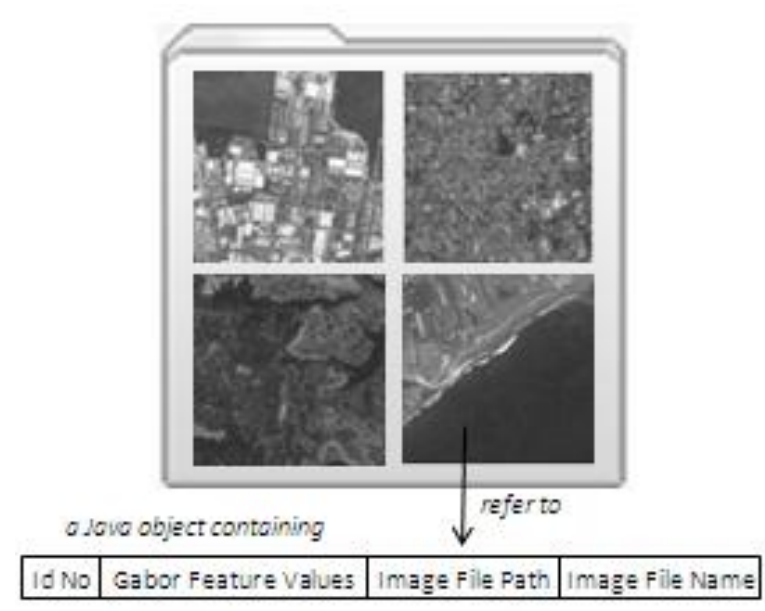

Gambar 1. Contoh struktur basis data menggunakan folder dan Java object serialization.

\section{Konstruksi Basis Data Menggunakan Folder dan Java Object Serialization}

Java Object serialization merupakan suatu proses penyimpanan status suatu objek dalam representasi suatu urutan byte, termasuk juga proses pembangunan kembali urutan byte tersebut menjadi objek terkait di masa yang akan datang ketika objek tersebut dibutuhkan [2]. Java serialization API (Application Programming Interface) menyediakan mekanisme standar untuk pengembang dalam mengelola proses object serialization tersebut.

Dalam membangun suatu sistem pencarian citra berbasis isi untuk aplikasi penginderaan jarak jauh, Aditya dkk. [3] telah menggunakan sistem basis data yang sederhana. Citra disimpan pada suatu folder yang telah ditentukan, dan fasilitas Java object serialization digunakan untuk merekam informasi citra terkait. Struktur basis data dengan pendekatan ini dapat dilihat pada Gambar 1.

Citra-citra foto satelit disimpan pada suatu folder. Pada contoh aplikasi tersebut, untuk setiap citra satelit dikaitkan dengan informasi yang disimpan sebagai rekaman yang terdiri dari nomor identitas, atribut isi citra yang direpresentasikan dalam nilainilai fitur Gabor, kelas-kelas objek penutup lahan yang ada pada citra terkait disertai dengan informasi luasannya, petunjuk path dimana berkas citra terkait disimpan, serta nama berkas citranya. Informasi ini disimpan sebagai objek dari suatu Java class yang menerapkan antar muka java.io.Serializable Interface. Gambar 2 menyajikan contoh dari kode suatu Java class yang mengandung informasi nama berkas citra yang akan disambungkan atau dikaitkan.

Selanjutnya, penetapan objek terkait juga perlu dilakukan dengan menggunakan fasilitas java.io.ObjectOutputStream class. Pada akhirnya, proses penyambungan diselesaikan dengan menuliskan objek tersebut pada suatu berkas yang spesifik. Gambar 3 menyajikan contoh kode yang diperlukan untuk melaksanakan prosedur tersebut. Objek yang telah ditetapkan tersebut dapat dibangun kembali dengan membaca urutan byte yang tersimpan pada berkas terkait, dan objek dapat dibangun kembali sebagai replika dari objek aslinya.

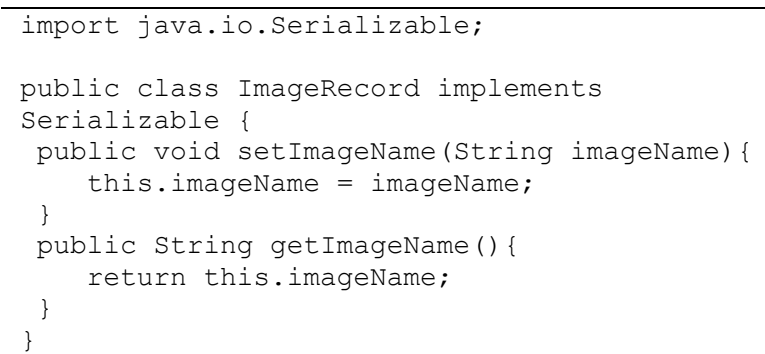

Gambar 2. Contoh kode suatu Java class yang menerapkan proses java.io.Serializable Interface.

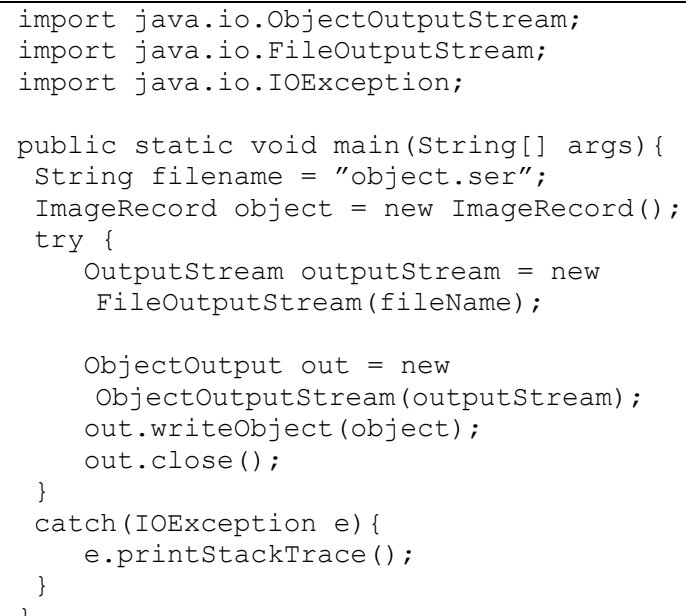

Gambar 3. Contoh kode suatu Java main class untuk penetapan suatu objek.

Sistem pencarian citra berbasis isi tersebut menggunakan proses kueri berdasarkan suatu contoh citra. Sistem akan memberikan respon dalam bentuk sederetan citra yang serupa dengan contoh citra yang diberikan pengguna, dengan urutan mulai dari citra yang paling serupa sampai ke citra yang paling tidak serupa [3]. Proses dimulai dengan melakukan ekstraksi nilai-nilai fitur Gabor dari citra contoh. Nilai-nilai fitur Gabor yang diperoleh kemudian dibandingkan dengan nilai-nilai fitur Gabor dari setiap citra yang ada di basis data. Tingkat keserupaan antara citra contoh dan setiap citra pada basis data diukur dengan metrik jarak Euclidean. Pada akhirnya sistem menampilkan citra-citra yang mempunyai keserupaan dengan contoh citra, dimulai 
dengan citra yang memiliki jarak Euclidean terkecil dengan citra contoh.

\section{Konstruksi Basis Data Menggunakan $M y S Q L$}

MySQL adalah open source SQL (Structured Query Language) DBMS yang dikembangkan, didistribusikan, dan didukung oleh MySQL AB, suatu perusahaan komersial yang didirikan oleh pengembang-pengembang MySQL [4]. MySQL merupakan suatu server yang melakukan proses penambahan, penggunaan, serta pemrosesan data yang disimpan suatu basis data pada komputer.

Dalam membangun basis data sistem pencarian citra berbasis isi untuk aplikasi batik, E. Margaretha telah menggunakan MySQL. Gambar 4 di bawah ini menyajikan struktur basis data dari sistem yang dibangun.

\begin{tabular}{|l|l|}
\hline Field & Type \\
\hline ImageID & integer \\
\hline ImageName & varchar \\
\hline ImageFile & longblob \\
\hline ImageOrigin & varchar \\
\hline ImageCategory & varchar \\
\hline GaborValue & longblob \\
\hline
\end{tabular}

Gambar 4. Struktur basis data menggunakan $M y S Q L$ untuk sistem pencarian citra batik berbasis isi.

Pada pengembangan awal, basis data yang dibangun hanya terdiri dari satu tabel. Isi dari tabel adalah sebagai berikut:

a. ImageID menyatakan nomor identitas citra batik yang direpresentasikan dalam integer

b. ImageName menyatakan nama berkas citra batik yang direpresentasikan varchar

c. ImageFile merupakan berkas citra dalam bentuk blob

d. ImageOrigin menyatakan tempat asal dari pola batik yang direpresentasikan dalam varchar

e. ImageCategory menyatakan nama dari kategori atau jenis atau tipe atau pola batik yang dinyatakan dalam varchar

f. GaborValue menyimpan nilai-nilai fitur Gabor yang dihitung dari citra batik dan dinyatakan dalam real

Pada awalnya perlu dibangun basis data dalam $M y S Q L$ sebelum tabel basis data dibuat. Proses pembentukan basis data dalam MySQL dilakukan dengan mengeksekusi suatu kueri dari Java. Dalam

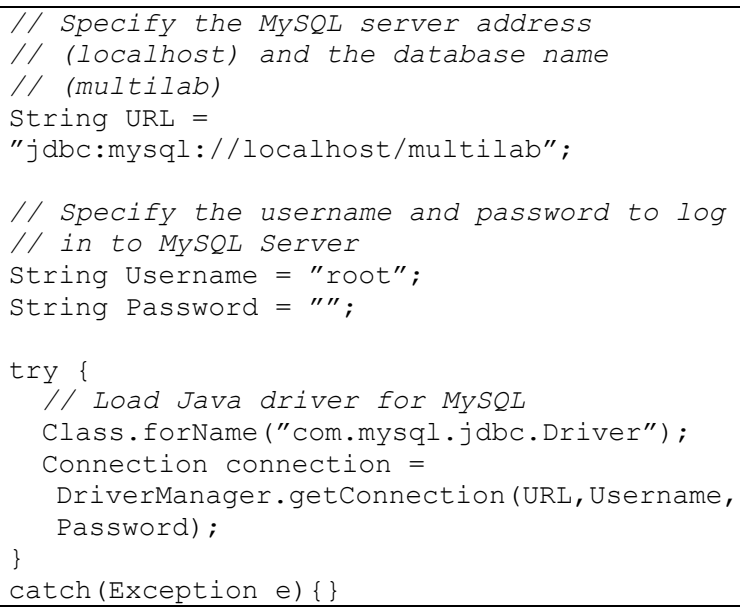

Gambar 5. Contoh kode Java untuk membangun koneksi antara Java dan MySQL.

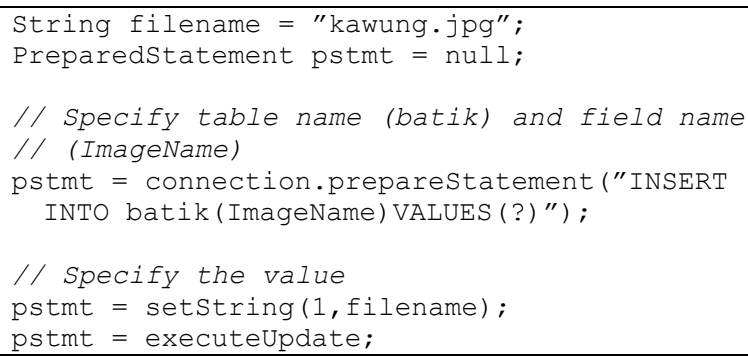

(a)

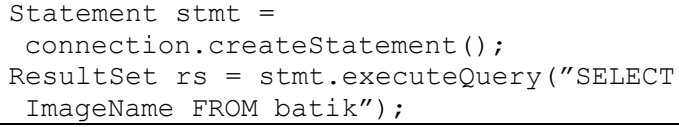

Gambar 6. Contoh kode Java suntuk menjalankan perintah kueri $S Q L$ menggunakan:

(a) java.sql.PreparedStatement; dan

(b) java.sql.Statement Interfaces.

hal ini perlu dibangun koneksi antara Java dan MySQL. Suatu Java driver telah digunakan untuk mengubah JDBC (Java Database Connectivity) menjadi koneksi ke protokol jaringan yang digunakan oleh MySQL. Gambar 5 memperlihatkan contoh kode untuk membangun koneksi tersebut.

Setelah koneksi dibangun, maka basis data dengan MySQL dapat diakses dengan menggunakan beberapa classes yang ada di java.sql package. Pada dasarnya, ada dua cara untuk menjalankan perintah kueri pada $S Q L$. Cara yang pertama dapat menggunakan instruksi interface java.sql.Statement untuk melaksanakan perintah kueri $S Q L$ yang statis. Sebagai contoh, instruksi tersebut dapat digunakan untuk menjalankan kueri SQL select. Cara yang kedua dapat menggunakan interface 
Penerapan Basis Data Citra pada Sistem Pencarian Citra Berbasis Isi: Menggunakan Fasilitas Java Object Serialization dan Menggunakan Fasilitas MySQL

java.sql.PreparedStatement untuk melaksanakan perintah kueri $S Q L$ yang dinamis dan biasanya memerlukan konversi parameter. Sebagai contoh, instruksi tersebut dapat digunakan untuk menjalankan kueri $S Q L$ update.

Pada pengembangan aplikasi batik, java.sql.PreparedStatement interface telah digunakan untuk menyusun tabel dari basis data sistem pencarian citra batik berbasis isi. Selain itu, untuk memilih data dari tabel, telah digunakan java.sql.Statement interface. Gambar 6 memperlihatkan cara penggunaan kedua interfaces.

Sistem yang dibangun menjalankan proses pemilihan data dari tabel basis data menggunakan $P H P$. Koneksi antara $P H P$ dan $M y S Q L$ dilakukan dengan $A D O d b$ yang merupakan suatu database abstraction library untuk PHP yang digunakan untuk melakukan koneksi dengan server basis data. Selanjutnya, kueri $S Q L$ select dapat dijalankan melalui koneksi yang sudah diciptakan oleh ADOdb.

Gambar 7(a) menyajikan contoh kode $P H P$ untuk membangun koneksi antara $P H P$ dan $M y S Q L$, dan Gambar 7(b) memperlihatkan contoh kode untuk menjalankan kueri $S Q L$ select.

\section{Pembahasan}

Pembahasan mencakup beberapa aspek dari basis data yang dapat mendukung efisiensi dari suatu sistem pencarian citra berbasis isi. Selain itu juga akan dibandingkan penyusunan struktur basis data menggunakan dua pendekatan yang dibahas pada Bagian 2 dan 3.

Suatu sistem pencarian data cenderung membutuhkan respon yang cepat untuk setiap kueri SQL select. Untuk itu fasilitas data indexing menjadi penting untuk mencapai optimasi dari pelaksanaan proses kueri. Proses indexing digunakan untuk mengelola struktur internal basis data, terutama dengan mengenali bagian data yang sering diakses sehingga kueri bagian data tersebut dapat dilaksanakan dengan efisien. Dengan kata lain, dengan indexing pencocokan kueri dapat dilakukan secara efektif dan proses pencarian pada basis data dapat dilaksanakan dengan lebih efisien.

Struktur basis data yang dibangun dengan pendekatan folder dan Java object serialization, memungkinkan pengembang untuk membangun sistem indexing yang sesuai kebutuhan. Sebagai contoh: pada aplikasi dokumen teks dapat dibuat indeks berdasarkan kata kunci, dan pada aplikasi citra dapat dibuat indeks berdasarkan blok kunci (key block) [5]. Walaupun untuk merancang dan menerapkan indexing pada struktur basis data ini memerlukan upaya tertentu, namun struktur basis

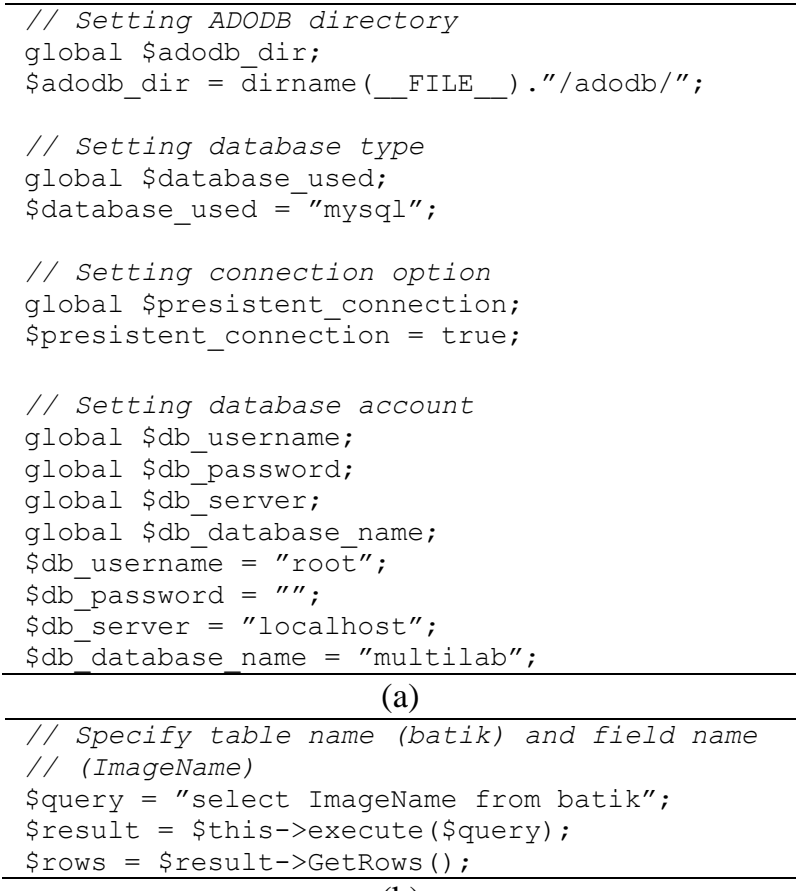

(b)

Gambar 7. Contoh kode PHP untuk: (a) membangun koneksi antara $P H P$ dan $M y S Q L$; dan (b) menjalankan kueri $S Q L$ select.

data ini sangat berguna untuk menyimpan dan menyusun indeks dari citra yang isinya tidak terstruktur yang direpresentasikan dalam bentuk graf $[5,6]$.

Pada sisi yang lain, struktur basis data yang menggunakan MySQL secara mudah dapat langsung menggunakan prosedur yang tersedia untuk indexing. Sistem pengelolaan basis data $(D B M S)$ seperti $M y S Q L$ telah dianggap sebagai sistem yang tangguh untuk melaksanakan penyimpanan dan perancangan indexing data yang terstruktur. Selain itu, struktur basis data ini secara praktis dapat menangani jumlah data yang besar. Indexing pada MySQL dapat dilakukan dengan sangat mudah, hanya mengatur beberapa variabel. Bagian data yang sering diakses dengan mudah dipilih dan diindeks. MySQL memberikan fleksibilitas untuk mengubah struktur basis data dan menyediakan mekanisme indexing yang komplek. Walaupun struktur basis data ini membutuhkan waktu perancangan yang lebih lama, namun tetap menjamin waktu dan usaha pengembangan yang relatif lebih sedikit.

Bagaimanapun, efisiensi dari perancangan indexing sangat dipengaruhi oleh karakteristik dari data. Data yang mempunyai struktur yang kompleks terkadang lebih baik dicari menggunakan representasi struktur data seperti Heap Tree dari pada struktur data 
B-Tree. Dalam prakteknya, pengguna sangat tergantung pada fasilitas struktur data dan prosedur indexing yang disediakan. Selain itu, DBMS juga tidak biasa digunakan untuk membangun struktur basis data yang datanya tidak terstruktur dengan baik, dimana transformasi data ke bentuk tabel-tabel yang berhubungan menjadi sulit.

$D B M S$ juga menyediakan dukungan untuk mengatur wewenang untuk akses data terutama dalam konteks pengguna yang jamak, penggunaan berbagai antar muka untuk pengguna yang jamak, serta pengelolaan integritas data [7]. Dukungan tersebut tidak tersedia dan harus diterapkan secara manual pada struktur basis data dengan pendekatan pertama (folder dan Java object serialization). Karena sistem pencarian citra berbasis isi lebih banyak menggunakan kueri berdasarkan SQL select dibandingkan dengan kueri $S Q L$ insert dan $S Q L$ update, maka aspek basis data yang berkaitan dengan proses penyisipan dan proses pembaruan data, seperti pengelolaan akses secara konkuren dan penanganan redundansi data, menjadi tidak terlalu penting.

Optimasi kueri juga dapat ditingkatkan melalui proses clustering data yang sering diakses. Proses clustering juga dapat mengurangi jumlah data yang harus dibandingkan dengan contoh citra pada suatu kueri. Secara spesifik dapat dikatakan bahwa contoh citra hanya perlu dibandingkan dengan kelompok data (cluster) yang mempunyai nilai atribut yang serupa. Mekanisme proses clustering dapat diterapkan pada struktur basis data dengan pendekatan pertama dengan cara yang sederhana, yaitu dengan membangun subfolder untuk setiap kelompok data dan menyusun program clustering. Di sisi lain, pada struktur basis data dengan pendekatan kedua, dapat diupayakan pembuatan tabel-tabel atau atribut baru yang mendefinisikan adanya kelompok (cluster) pada data.

\section{Penutup}

Makalah ini membahas dua struktur basis data. Model yang pertama menggunakan folder dan Java object serialization, dan model kedua menggunakan basis data $M y S Q L$. Fokus pembahasan adalah pada aspek struktur basis data yang mendukung terpenuhinya kebutuhan sistem pencarian citra berbasis isi yang efektif dan efisien.

Beberapa karakteristik yang sering dijumpai pada sistem pencarian citra berbasis isi dan proses-proses yang sering dibutuhkan antara lain adalah:

1) Proses indexing dan clustering merupakan proses yang dibutuhkan untuk mendapatkan sistem yang efisien;
2) Lebih banyak melakukan kueri proses pencarian (select) daripada penyisipan (insert) dan pembaruan (update) data;

3) Sering dijumpai adanya kebutuhan membangun basis data citra yang tidak terstruktur; dan

4) Jumlah data yang disimpan juga cukup besar. Dari pembahasan yang telah dirinci di Bagian 4, dapat disimpulkan bahwa:

1) Untuk data yang terstruktur, $D B M S M y S Q L$ (model kedua) menyediakan kemudahan dalam proses indexing dibandingkan dengan model pertama.

2) Proses clustering dengan mudah diterapkan pada model pertama, yaitu dengan merancang sub-folder dan program clustering. Pada model kedua perlu disusun tabel atau atribut baru yang memberikan informasi tentang adanya cluster pada data.

3) Data yang tidak terstruktur memerlukan struktur data yang khusus yang biasanya bukan termasuk pada struktur data generik yang disediakan di DBMS MySQL (model kedua). Dalam hal ini model pertama lebih cocok untuk menanganinya.

4) Sistem pencarian citra berbasis isi lebih banyak menggunakan kueri select dibandingkan kueri insert dan update data. Dalam hal ini kedua model mendukung kebutuhan tersebut dengan baik.

5) Untuk data yang berukuran sangat besar, model kedua dapat mendukung pengelolaan data secara lebih mudah dan fleksibel.

Sekalipun model DBMS MySQL tidak begitu cocok untuk data yang tidak terstruktur, pada umumnya model ini dianggap cukup baik untuk menangani jumlah data yang besar, dan memberikan dukungan yang baik dalam penyimpanan dan manipulasi data, serta dapat mengurangi upaya dan waktu yang dibutuhkan pada pengembangan sistem.

\section{Penghargaan}

Rasa terima kasih ditujukan kepada Bapak Andreas Febrian yang telah membantu dalam penerapan sistem dan Bapak Ahmad Nizar yang telah memberikan saran-saran yang berharga. 


\section{REFERENSI}

[1] T. Andrysiak and M. Choras, "Image Retrieval Based On Hierarchical Gabor Filters," Int. J. Appl. Math. Comput. Sci., vol. 15, no. 4, pp. 471-480, 2005.

[2] T. Greanier. "Discover the secrets of the Java Serialization API," Sun Developer Network: http://java.sun.com/developer/technicalArticles/P rogramming/serialization/, July, 2000 [September 12, 2008].

[3] E. Aditya, A. Murni, and Wiweka. "Information Mining in Remote Sensing Application," The $1^{\text {st }}$ Indonesian Geospatial Technology Exhibition: Poster Presentation, Jakarta, August 23-27, 2006.
[4] MySQL AB. "MySQL 3.23, 4.0, 4.1 Reference Manual," 1997-2008.

[5] E. G. M. Petrakis, C. Faloutsos, and K. -I. Lin. "ImageMap: An Image Indexing Method Based on Spatial Similarity," Knowledge and Data Engineering, IEEE Transactions, Volume 14, Issue 5, pp.979-987, September/October 2002.

[6] S. Aksoy. "Modeling of Remote Sensing Image Content using Attributed Relational Graphs," Department of Computer Engineering, Bilkent University, Ankara, 06800, saksoy@cs.bilkent.edu.tr, [March 1, 2088].

[7] R. Elmasri and S. B. Navathe. Fundamental of Database Systems, Pearson Education, Inc, MA: Boston, 2004. 